\title{
Front-line biographies of natives of the Removsky selsoviet of the Borodulikha District (East Kazakhstan) on the basis of materials from the documents of the Central Archives of the Ministry of Defence, Russian Frderation.
}

DOI: $10.31551 / 2410-2725-2019-5-2-296-310$

\section{Schmider Marina Aleksandrovna}

Doctor of Philosophy, employee of the City Museum of Vechta, member of the Center for the Study of Catholicism and the Resistance Movement at the University of Vechta / Germany. Federal Republic of Germany. 49377 Vechta, Zitadelle 15. E-mail: marina_schmieder@live.de.

\begin{abstract}
In the beginning of the 20th century a number of villages emerged in the eastern part of the current Borodulikha district in East-Kazakhstan. The study of these villages' history rarely attracts the attention of researchers. However, while the villages of the German enclave (which had been in existence until the 1990s) sometimes arouse a few researchers' interest, the history of the Removsky selsoviet remains unexplored. The selsoviet was centrally located within the German enclave, the majority of its inhabitants being Kazakhs and Ukrainians. To this day, two of the three initial villages ( $\mathrm{N}$. Kireevka and Ordzhonikidze) have already disappeared from the map of East-Kazakhstan and the village Remki is gradually disbanding. Most recruits of the eastern part of the Borodulikha district originated from the selsoviets Removsky and Peremenovsky. Over the past ten years, the Ministry of Defense (Russia) has published documents from its Central Archive (TsAMO RF) on the Internet. On the basis of these documents as well as of results from a survey among Remky residents, the author was able to collect information about the front-line soldiers of the Removsky selsoviet. This article devotes itself to the analysis of the current list of combatants and of the table containing their personal details. It deals with the Removsky soldiers' contribution to victory, their battle- and work biographies and the turning points of their lives. It has come to light that the number of soldiers killed in action was three times higher than it had been estimated before (about 90 men). The article does not only present the heroic but also the tragic biographies of officers and Red Army men. The author names and explains facts surrounding their wounds, captivity in war and punishments through the decisions of the military court. Documents about the war decorations of Removsky soldiers shall serve as an example of the Red Army commanders' motives for the award of such war decorations to their subordinates. The information gained from the Central Archive documents on the biographies of the Removsky combatants contribute to the exploration of the history of East-Kazakhstan's villages and their inhabitants.
\end{abstract}

Keywords: East Kazakhstan region, Semipalatinsk, Borodulikha district, Great Patriotic War, local history, the Soviet period, research methods.

\section{Ресей Федерациясының ҚМОМ құжаттарының материалдарындағы Бородулиха ауданының Ремовский ауылдық кеңесі (Шығыс Қазақстан) тұрғындарының майдандық өмірбаяндары}

\section{Шмидер Марина Александровна}

Философрия докторы, Фехта қаласының қалалық мұражайының қызметкері, Фехта/Германия университеті жанындағы «Католицизм және қарсыласу қозғалысын зерттеу орталығының» мүшесі. Германия Федеративтік Республикасы. 49377 Vechta, Zitadelle 15. E-mail: marina_schmieder@live.de.

\begin{abstract}
Аңдатпа. XX ғасырдың басында Шығыс Қазақстан облысының қазіргі Бородулиха ауданының шығыс бөлігінде қонысаударушылардың бірнеше елді-мекендері пайда болған. Бұл поселоктардың тарихын зерттеуге зерттеушілер сирек көңіл бөледі. Неміс анклавы зерттеушілердің назарына іліккенмен, Ремовский ауылдық кеңесінің тарихына қызығушылық жоқ десе болады. Соңғысын көбінде қазақтар мен украиндар мекендеген. Ауылдық кеңес неміс анклавының орталығында орналасқан. Бүгінгі күні үш ауылдық кеңестің екеуі (Новая Киреевка мен Орджоникидзе) ШҚО картасынан жойылса, ал Ремки селосы да солардың тағдырын қайталар алдында. Ауданның шығы бөлігінен ҰОС-на шақырылғандардың көпшілігін Ремовский пен Переменовский ауылдық кеңесі құрайды. Мақала ҰОС-на қатысушылардың ағымды тізімін талдауға арналған және олар туралы жеке мәліметтер көрсетілген кестелерден тұрады. Мақалада ремовшылдықтардың Жеңіске қосқан үлесі, олардың соғыстағы ерліктері мен еңбектегі өмірбаяндары, тағдырлары қарастырылады. Округ бойынша қайтыс болғандардың саны 90 немесе бұрын көрсетіліп жүргеннен 3 есе көп екендігі анықталды. Мақалада офицерлер мен
\end{abstract}


қатардағы қызыл жауынгерлердің ерліктері ғана емес, сонымен қатар қайғылы тағдырлары да көрсетіледі. Автор олардың жарақат алу, тұтқынға түсу және әскери трибуналдың үкімі бойынша жазалану фактілерін талдаған. Ремовлықтардың марапат парақтарының негізінде командирлердің қол астындағыларды әскери марапаттармен марапаттау себептері айқындалған. МOОМ-ның құжаттарының негізінде олардың әскери өмірбаяндарының фрактілері анықталып, ШҚО елді-мекендері мен олардың тұрғындарының тарихын зерттеуге үлес қосады.

Түйінді сөздер. Шығыс қазақстан облысы, Семей, Бородулиха ауданы, Ұлы Отан соғысы, өлкетану, кеңестік кезең, зерттеу тәсілдері

\title{
Фронтовые биографии уроженцев Ремовского сельсовета Бородулихинского района (Восточный Казахстан) на материале документов ЦАМО РФ
}

\section{Шмидер Марина Александровна}

Доктор философиии, сотрудник Городского музея г. Фехта, член „Центра изучения католицизма и движения сопротивления" при университете Фехта/Германия. Федеративная республика Германия. 49377 Vechta, Zitadelle 15. E-mail: marina_schmieder@live.de.

Аннотация: В начале XX века в восточной части современного Бородулихинского района Восточно-Казахстанской области возник ряд переселенческих посёлков. Изучение истории этих посёлков редко привлекает внимание исследователей. Если селения немецкого анклава попадают в их поле зрения, то история посёлков Ремовского сельсовета - нет. Последний населяли преимущественно казахи и украинцы. Находился сельсовет в центре немецкого анклава. Сегодня из трёх посёлков сельсовета два (Новая Киреевка и Орджоникидзе) уже исчезли с карты ВКО, а село Ремки исчезает. Основной костяк призывников ВОВ из восточной части района происходил из сёл Ремовского и Переменовского c/c.

За последнее десятилетие на сайтах Минобороны РФ были опубликованы документы ЦАМО РФ. На основании этих документов и по результатам анкетного опроса населения, автору удалось собрать данные на фронтовиков Ремовского с/с. Статья посвящена анализу текущего списка участников ВОВ и таблицы с их персональными данными. В статье рассматривается вклад ремовцев в Победу, их боевые и трудовые биографии и перепитии их судеб. Выяснилось, что павших было ок. 90 или в 3 раза больше, чем предполагалось в округе ранее. В статье представлены не только героические, но и трагические биографии офицеров и рядовых красноармейцев. Автор анализирует факты их ранений, пленения и наказаний по приговору военного трибунала. На примере наградных листов ремовцев отслеживаются мотивы командиров для награждений подчинённых различными боевыми наградами. Выявленные из документов ЦАМО фракты боевых биографий ремовцев, вносят вклад в дело изучения истории поселений ВКО и их жителей.

Ключевые слова: Восточно-Казахстанская область, Семипалатинск, Бородулихинский район, Великая Отечественная война, краеведение, советский период, приемы исследования.

\section{UDC/УДК 93/94-908}

\section{Фронтовые биографии уроженцев Ремовского сельсовета Семейского региона на материале документов ЦАМО РФ}

\author{
M.A. Шмидер
}

Введение. В 1970-ые годы на мемориальной стеле комплекса Славы в с. Переменовка Бородулихинского района ВКО были выбиты имена около 30 павших на фрронтах ВОВ жителей Ремовского сельсовета (1918-1975 гг.). В 1997 году в справочнике „Книга Памяти“ Семипалатинской области авторы обнародовали новые имена убитых и пропавших без вести ремовцев. (Книга Памяти, 1996) Однако разработка более полного списка павших и вернувшихся с войны односельчан стала возможна в последнии десять лет. С 2008 года Министерство Обороны РФ начало публикацию цифровых копий 
документов своего Центрального Архива (ЦАМО РФ) и записей из более 1000 томов Книги Памяти. Для этого использовались сайты общедоступных электронных банков: http://podvignaroda.mil.ru, https://pamyat-naroda.ru и https://obd-memorial.ru. Почти одновременно с названными проектами, в 2012 году, на сайте Министерства Обороны Республики Казахстан в „Банке данных погибших и пропавших без вести в период Великой Отечественной войны военнослужащих призванных с территории Казахстана" был опубликован алфравитный список казахстанцев-фронтовиков. https://mod.gov.kz/ memorial/pages/e/e1.html). В период оцифровки и публикации архивных документов ЦАМО РФ развивалось международное общественное гражданскопатриотическое движение „Бессмертный полк". Оба события нулевых дали новый импульс исследованию боевых биографий советских фрронтовиков и способствовали повышению интереса общественности к увековечению памяти погибших.

Материалы и методы. При помощи опроса, проведённого в 2015-2019 гг. среди жителей села Ремки, а главным образом, благодаря опубликованным документам ЦАМО РФ, автору удалось составить таблицу с персональными данными на участников ВОВ, уроженцев и жителей Ремовского с/с. Собранная информация - ФИО, года и места рождения, гибели и призыва, воинские части, звания и награды позволяют воссоздать фронтовую историю односельчан. Среди использованных документов преобладают донесения о потерях личного состава, в том числе о безвозвратных и санитарных, приказы подразделений, наградные листы, извещения о гибели, учётно-послужные карточки офицеров и анкеты военнослужащих.

В текущем списке автора насчитываются имена примерно 40 военнослужащих со славяноязычными и около 110 с тюркоязычными фрамилиями. Следует учесть, что в документах военного времени встречаются ошибки не только в написании ФИО, особенно в тюркоязычных именах и фамилиях. Некоторые военнослужащие, указанные в документах погибшими или пропавшими без вести, например, 3. Бакебаев, И. А. Соколовский и И. Матайбаев, к счастью, остались живы. В процессе ознакомлениясо списком, родственники уточняют и корректируют данные на фронтовиков.

Анкетирование в интернете - удобная возможность опроса, так как бывшие жители сельсовета проживают не только в различных уголках Казахстана и в странах ближнего зарубежья, но и в Германии. Сегодня из трёх его посёлков два, Новая Киреевка и Орджоникидзе, уже исчезли с карты ВКО, а миграция в регионе ведёт к запустению села Ремки. Если в 1999 году здесь проживало 158 человек, то через 10 лет их осталось уже 89. (HPK, 2009: 227).

Обсуждение. Изучение истории поселений Ремовского сельсовета и их жителей не вызывало интереса исследователей. В мемуарной же литературе с. Ремки упомянается. (Аманжолов, 2012: 15-16). Краеведы из Казахстана, России и Германии охотно интересуются историей немецких переселенческих посёлков в округе села Ремки. Интерес вызывает особенно большое, немецкое католическое село Мариенбург/Переменовка. (Недзелюк, 2006; Shaidurov, 2018; Даутов, 2011).

Для интерпретации таких явлений войны, как плен и наказания военнослужащих по приговору военного трибунала в статье использовались работы российских исследователей. (Воробьев, 2014; Букейхайнов, 2013; Исаев, 2015). Кроме того при работе над публикацией привлекались 
справочники, сборники документов игеографические карты. (Справочник, 2006; Карта, 1911)

Результаты. Из трёх селений Ремовского сельсовета, Бельагачского (с 1944 г. Бородулихинского) района Семипалатинской области - Ремков, Новой Киреевки и Орджоникидзе были призваны на фронт более 150 мужчин. Это были сыновья украинских, казахских, татарских переселенцев и казахских старожилов. Их родители основали в начале XX века на переселенческих участках N77 и N78, на западной окраине Ремовской степи три небольших населённых пункта. (Карта, 1911) Особенность их местоположения состояла в том, что они находились в центре большого немецкого анклава из восьми переселенческих посёлков.

В первые годы войны селения, на чьих улицах ещё недавно звучал смех вперемешку с тюркской и славянской речью, изменились. Поменялся не только жизненный настрой, но и состав жителей. С колхозных фрерм, полей и пастбищ исчезали с каждым годом мужчины призывного возраста. На фрронт ушло почти всё молодое мужское поколение переселенцев. Часть оставшихся жителей тоже покинула посёлки, найдя поддержку и опору у своих родственников в округе. Пережить тяжёлое время сообща было легче. Постепенно в Ремовском сельсовете появилось много новых лиц. Это были дети родственников, одни или с матерями, эвакуированные из больших городов (Ленинграда и Волгограда) русские семьи, а также депортированные с Волги и Кавказа немецкие и чеченские семьи. Односельчане жили в постоянной тревоге за жизни своих родных. Больше всего в те годы боялись увидеть на пороге дома мрачное лицо сельского почтальона. Он носил в своей сумке не только письма родных с фронта, но и извещения о их гибели. Некоторым многодетным ремовцам похоронки приносили часто. У переселенца Михаила П. Пазий ушли на фронт четыре сына, двое из них погибли в возрасте 19-20 лет. Иллариону Д. Соколову война оставила только одного сына - Савелия. Терентий и Николай не вернулись. Ввиду того, что сыновья в казахских семьях имели зачастую разные фамилии, именуясь либо по имени отца, либо по имени деда, сложно выявить родных братьев в числе фронтовиков. Тем не менее из донесений о потерях следует, что погибли или пропали без вести по трое красноармейцев Мусабаевых, Дюсембековых, Мамытовых, Смагуловых, Турганбаевых, Тусуповыхи Мукашевых.

В летописи Великой Отечественной, как и любой другой войны, есть страницы не только геройских подвигов. В ней истории гибели и ранений миллионов солдат и офицеров, а также пленение их врагом или наказания по приговору военных трибуналов или постановлений командиров и особых совещаний. Из примерно 150 ушедших на фронт ремовцев, домой вернулись только около 60 человек или меньше половины. Из ок. 90 погибших, до 50 военнослужащих погибли или пропали без вести в первые месяцы войны или в свой первый год службы. Зачастую павшие не успели удостоиться боевых наград. Не сохранилось документов и писем с фрронта с инфрормацией об их боевой биографии и обстоятельствах гибели. Однако общеизвестно, что на их долю выпали тяжёлые моральные и фризические испытания - они принимали участие в наступательных и оборонительных боях, после каждого боя теряли и хоронили товарищей, страдали от ранений и пребывали в экстремальных боевых условиях.

Наградные статусы предусматривают награждения за тяжёлые и многократные ранения. 22-летний младший сержант и командир стрелкового отделения Балташ Жапаров был представлен к медали „За отвагу“ за три 
ранения. Такой же медали были удостоены и оба родных брата Руденко многодетный Семён М. 1909 г.р. и холостой Сеня М. 1913 г.р. Старший брат был ранен во время боевого задания по подрыву железнодорожного полотна при штурме города-крепости Кёнигсберг весной 1944 года. Младший брат получил тяжёлое ранение в голень в мае 1942 года на Северо-Западном фронте, сопровождая в качестве ординарца комиссара полка Панфиловской дивизии на командный пункт. Младший лейтенант Камадан Оразгалиев был удостоен в августе 1946 ордена „Красная Звезда“ за тяжёлое ранение в плечо с повреждением грудной клетки и ребра. Врачи присвоили ему статус инвалида ВОВ II группы.

После вовзращения домой ветераны-инвалиды не споспобны были вести полноценную жизнь. Они подолгу находились на лечении в больницах и умирали, не дожив до старости. Шакир Аубакиров лишился на фронте в результате тяжёлой контузии слуха. У Семёна М. Руденко разрывная пуля повредила бедренную кость и вызвала тяжёлую болезнь кости. Последний перед смертью год он провёл в больнице г. Семипалатинска и умер в возрасте 53 года. Наводчик ручного пулемёта 422 сп 170 сд Кали Турганбаев дважды был ранен. За своё мужество и тяжёлое ранение в бою за д. Ясиновку Гомельской области в июне 1944 года младший сержант был награждён „Орденом Славы III степени“, а позже медалью „За боевые заслуги“. Осколок мины, войдя между пальцами его кисти, вышел через плечо, разорвав мышцу.

В донесениях о потерях зафиксировано, что в плену или под подозрением захвата в плен находились Мукатай Анибаев, Смагул Майлыбаев и Аслан Саимбаев/Саянбаев. Наряду с ними вернулись в родное село из плена Мукатай Турганбаев, Мухаметжан Рахимбеков, Айтказы Сатбеков и старший сержант Хасим И. Уралбаев. Эти красноармейцы оказались в плену в первые месяцы войны. Не вернулся домой сын ремовца Сарсекена Кадырманова, Жумагали С., пленённый во время Сталинградской битвы.

В статистических исследованиях на тему „Советские военнопленные в годы ВОВ" называются следующие цифры: больше 4559,0 тыс. военнослужащих оказалось в годы войны в плену. Из них вернулись домой меньше половины или 1836, 5 тыс. человек. (Кривошеев и др., 2001: 453). Некоторых ремовцев-военнопленных ждало в СССР тюремное заключение, а остальных ограничения в правах и пересуды земляков. После окончания войны военнопленные направлялись в рабочие батальоны на предприятия угольной и лесной промышленности. Прямые родственники пленных лишались в военное время денежных пособий и других льгот. В отношении их действовал ряд ограничений при поступлении на работу, учёбу итд. Из-за карательной политики власти в обществе сложилось скептическое отношение к бывшим военнопленным. Исследователь темы „Реабилитация советских военнопленных в СССР", юрист С. М. Воробьев, считает, что в отношении пленных и их семей во время и после войны советское государство совершало "правовой беспредел". (Воробьев, 2014). Уже через месяц после начала войны Ставка Верховного Главнокомандования издала приказ N270 от 16.08.1941. Он гласил, что каждый военнослужащий, оказавшись в окружении, обязан „драться до последней возможности" и уничтожать сдающихся в плен врагу. (https://www.1000dokumente.de). После проверки органами государственной безопасности в проверочно-фильтрационных лагерях было приговорено к тюремному заключению 339000 вернувшихся из плена советских военнослужащих. (Кривошеев и др., 2001: 453). В середине 1950ых комиссия по делам военнопленных под руководством маршала Г.К. Жукова 
резюмировала, что многие из них были незаконно репрессированы. Вместе с тем, жизнь советских военнослужащих в плену была полна лишений и опасности для жизни. Более двух миллионов советских военнопленных погибло от голода и эпидемий или было убито. (Кривошеев и др., 2001: 453). Их содержали в конюшнях, бараках, часто под открытым небом и использовали на различных тяжёлых работах.

Советское государство предпринимало с конца 1940-ых годов меры по политической реабилитации бывших советских военнопленных. Завершились они в период перестройки. Из данных Юбилейной картотеки награждений ЦАМО РФ следует, что правительство наградило бывших в плену ремовцев в 1985-ом, 1987-ом и 1990-ом годах юбилейными „Орденами Отечественной войны II степени “.

В текущем списке ремовцев-фронтовиков насчитывается около 30 военнослужащих сержантского состава Красной Армии. В младшем офицерском составе служили десять лейтенантов и один капитан. Звание капитана имел Василий Д. Каралаш (1923, Ремки - 1985, Семипалатинск). В начсостав Красной Армии входили преимущественно молодые ремовцы 19-25 лет: Камбар С. Аманов, Умеркан Аскаров, Григорий Н. Галушко, Иван Д. Губанов, Кумар К. Канапин, Куб(л)аш Мустафин, Василий Г. Касенов, Камадан Оразгалиев, Иван А. Соколовский и Анатолий С. Якуба. Из-за нехватки командиров, в том числе ввиду их высокой смертности на поле боя, офицерские кадры подготавливали в годы войны на ускоренных курсах. В учетно-послужной карточке офрицера с неполным средним образованием Василия Г. Касенова отмечено, что в декабре 1944 он закончил четырёхмесячные курсы младших лейтенантов 7 гв. армии. Уже через два месяца коммунист, имевший на фронтах ВОВ четыре ранения, погиб в бою на территории Чехословакии. Большая часть офицеров и сержантов из с. Ремки были членами или кандидатами в члены ВКП(б). Вернувшиеся с войны коммунисты, пополнили сельскую партийную организацию. Её коллектив был крупнее первичных организаций ВКП(б) соседних с Ремками немецких сёл.

Мало кто из выживших в первые годы войны ремовцев- фронтовиков остался без боевых наград. Наиболее часто награждались офрицеры, сержанты, разведчики, а также члены и кандидаты в члены партии. Первоочередное партийное задание коммунистов состояло в том, чтобы показывать в бою пример другим бойцам, воодушевлять их своей храбростью. Вместе с тем нередки случаи, когда рядовые беспартийные ремовцыкрасноармейцы удостаивались нескольких боевых наград.

В текущем списке боевых орденов и медалей односельчан насчитывается 20 орденов „Красной Звезды“, 16 медалей „За отвагу“, 11 медалей „За боевые заслуги“, 6 орденов „Славы“ и 5 орденов „Отечественной Войны“ разных степеней. При этом не учитывались юбилейные награды послевоенного времени. Многие военнослужащие из Ремовского с/с являются обладателями медалей „За оборону“, „За штурм“ или „За освобождение“ различных советских и европейских городов. Дважды орденоносцем „Красной Звезды“ являлся, погибший на фронте, лейтенант К. С. Аманов, а также ветераны войны лейтенанты К. К. Канапин и И. А. Соколовский. Дважды удостоился медали „За отвагу“ сержант-разведчик К. А. Раев.

Среди ремовцев-фронтовиков нет Героев Советского Союза, их героизм негромкий. Тем не менее и старшее, и молодое поколения отличились на фронте и в тылу. Многие ветераны не любили вспоминать войну. Боевые заслуги односельчан неизвестны зачастую ни их потомству, ни их землякам. 
Ниже приведены примеры подвигов военнослужащих различных родов войск и воинских званий из Ремовского с/с. В электронных банках данных опубликованы больше полусотни наградных листов ремовцев. В них командиры корпусов (батальонов и полков) поясняют, за что они представляют своих подчинённых к награде. При этом они не скупятся на такие слова, как „мужество”, „храбрость“ и „героизм“. Командование армий и фронтов либо отвечало на их запрос приказом о награждении, либо оставляло его без внимания. Случалось и так, что военнослужащие погибали, не дожив до приказа. Иногда, взамен запрошенной командиром награды, командование выделяло какую-либо другую. Ценность наградных листов состоит и в том, что они являются источником информации для воспроизведения картины боевых действий на различных участках фрронтов ВОВ.

Ряд боевых наград имел уроженец посёлка Новая Киреевка 1920 г.р., а в послевоенное время уважаемый земляками директор Бель-Агачской средней школы Кумар Канапьянович Канапин. До войны он получил педагогическое образование на историческом факультете. Первой своей награды ордена „Красной Звезды“ гв. старший лейтенант был удостоен в марте 1944 года. Будучи командиром взвода в артиллерийском полку, при прорыве обороны под Новгородом он умело корректировал огнём из боевых порядков пехоты. В результате было разрушено 100 метров траншеи, одно 75 мм орудие и до 15 вражеских солдат. Уже через полгода ст. лейтенант был вторично награждён орденом „Красной Звезды“. Он разведал один пулемётный ДЗОТ, пулемёты, наблюдательный пункт и склад с боеприпасами врага. Кроме того, в рукопашном ночном бою лично уничтожил трёх германских солдат. В конце войны на территории Германии офицер был дважды ранен в одном бою. Несмотря на травму, он продолжал успешно корректировать огонь батареи. При повторном ранении ст. лейтенант потерял сознание и был эвакуирован с поля боя'. Кумар К. Канапин похоронен в 1982 году на мусульманском кладбище села Ремки.

Ещё один уроженец с. Новая-Киреевка, лейтенант Камбар/Камир Аманов 1919 г.р. был удостоин нескольких боевых наград. За полгода, с февраля по август 1944 года, командир огневого взвода 12 мм-миномётов был награждён трижды. При прорыве обороны в июле его взвод в составе Прибалтийского фронта подавил 30 огневых точек и уничтожил до 35 солдат и офицеров противника ${ }^{2}$. В следующем бою взвод Аманова подавил огонь пушки. Через несколько недель после повторного награждения Орденом „Красной Звезды“ лейтенант пал в бою на территории Латвийской ССР.

Лейтенант Иван Андреевич Соколовский 1920 г.р. служил в танковых войсках. Командир взвода танка Т-34 за полгода три раза был представлен к наградам. Его воинское подразделение и машина уничтожили в боях за Будапешт и Вену четыре танка, пушку, бронетранспортёр, три пулемёта, два миномёта и до 150 солдат противника ${ }^{3}$.

Будущий капитан, а в конце 1943 года ещё двадцатилетний гв. лейтенант Василий Данилович Каралаш, воевал после призыва в Красную Армию на четырёх фронтах - Брянском, Северо-Западном, Степном и Украинском, где был дважды ранен. В середине ноября рота ПТР ПО 20-го воздушно-

\footnotetext{
${ }^{1}$ Наградной лист от 11.04.1944. ЦАМО (Центральный архив Министерства обороны Российской Федерации). Ф. 33. Оп. 690155. Д. 333. Л. 13.; Наградной лист от 4.11.1944. ЦАМО. Ф. 33. Оп. 690155. Д. 6525. Л. 23

${ }^{2}$ Наградной лист от 29.07.1944. ЦАМО. Ф. 33. Оп. 686196. Д. 4992. Л. 8.

${ }^{3}$ Наградной лист от 23.04.1945. ЦАМО. Ф. 33. Оп. 690306. Д. 3518. Л. 32.; Наградной лист от 15.03.1945. ЦАМО. Ф. 33. Оп. 690306. Д. 3519. Л. 7.
} 
десантного стрелкового полка, во главе со своим командиром лейтенантом Каралашем получила боевое задание - прикрыть при штурме правый фланг сопки. На следующий день германские подразделения пошли на пехоту в контратаку с 11-ю танками. Командир полка, гвардии майор Харисов записал после боя в наградном листе лейтенанта: „Несмотря на то, что в команде Каралаша осталось всего девять человек, при натиске пехоты и танков противника не отошли ни на один шаг. [...] Лично сам находился в боевых порядках пехоты, проявив мужеству и отвагу. Приняв на себя удар контраатаки противника, с горсткой храбрецов нанес врагу большие потери и ввёл его в замешательство"

В списках награждённых Орденом „Красной Звезды“ офицеров-ремовцев есть и имя Умеркана Аскарова 1914 г.р. За две недели до конца войны, 22 апреля 1945 года, стрелковый взвод под командованием младшего лейтенанта уничтожил у г. Гебельциг/Германия 16 солдат и станковый пулемёт противника. На следующий день его взвод первым прорвал оборону и увёл за собой весь батальон ${ }^{5}$.

Сержант Макен К. Дюсупов 1924 г.р. достиг призывного возраста в сентябре 1942. Прибыв на фрронт, кандидат в члены ВКП(б) ежегодно удостаивался боевой награды. Медаль „За отвагу“ командир отделения 278 сп заслужил в ноябре 1943 в Гомельской области, уничтожив своим противотанковым ружьём пулемётное гнездо противника. Последнюю свою награду „Орден Славы III“ степени „мужественный младший командир“ удостоился за то, что в бою первым ворвался в траншею противника, увлёк за собой других бойцов и уничтожил из автомата трёх вражеских солдат. два дня после приказа командования о награждении, 3 марта 1945 года, сержант пал в бою у г. Бан/Бранденбург.

Не только мужчины-уроженцы Ремовского сельсовета удостоились боевых наград. Среди сержантов-фронтовиков была и девушка - старшая дочь украинского переселенца Иосифа М. Руденко - Екатерина И. Руденко (19251997). Она ушла добровольцем на фронт из с. Калантырь, Новенского с/с в числе ста других девушек с Алтая. В Калантырь она переселилась с родителями из ремовского колхоза „Украинец". О боевой биографии Екатерины повествует наградной лист и письмо её командира в районную газету „К новым Рубежам". Медали „За отвагу“ медсестра удостоилась в августе 1944 года после того, как у д. Оле Латвийской ССР вынесла с поля боя одиннадцать раненых офицеров и солдат с их оружием ${ }^{7}$. Командир роты 256 сп 2 Прибалтийского фрронта лейтенант Михаил Д. Масюк, разыскивая после войны через газету Локтевского района санинструктора своего подразделения, отзывался о сержанте Е. Руденко с теплотой: „В 1943 году освобождали мы территорию Латвии. В одном из боев девушка была ранена (подорвалась на мине при выносе с поля боя раненого). Она была сильная духом, смелая. Не один десяток советских воинов спасла. С ранеными была всегда ласковой, обходительной. Как сейчас помню ее в забрызганном кровью халате среди раненых". (Масюк, Героическая девушка, 2005). После войны Екатерина И. (в замужестве Абдулина) работала аптекарем в пос. Березовка Бородулихинского района.

\footnotetext{
${ }^{4}$ Наградной лист от 24.11.1943. ЦАМО. Ф. 33. Оп. 690155, Д. 741. Л. 5.

${ }_{5}^{5}$ Наградной лист от 27.05.1945. ЦАМО. Ф. 33. Оп. 690306. Д. 2951. Л. 4.

${ }^{6}$ Наградной лист от 01.03.1945. ЦАМО. Ф. 33. Оп. 686196. Д. 3947. Л. 96.

${ }^{7}$ Приказ подразделения Прибалтийского фронта от 22.08.1944. ЦАМО. Ф. 33. Оп. 690155. Д. 6257. Л. 3.
} 
Известны имена ремовцев, служивших в конной и пешей разведке. Рядовые красноармейцы Канапья/Конон С. Раев, Иван И. Некрасенко, Мухит Мухамеджанов, а также сержанты-разведчики Назар Токаев, Гаяс С. Ибатулин и Фаиз Сарсенбаев были награждены за взятие „языков", за участие в засадах и в других операциях, связанных с проникновением в тыл врага.

Командир отделения взвода пешей разведки Назар Токаев 1917 г.р. поджидал осенью 1942 года противника в засаде. Младший сержант подпустил врага вплотную и только потом открыл огонь. Затем он преследовал убегающих солдат с криком „Ура!" и „Вперёд товарищи!“ Несмотря на ранение в ногу, он оставался в строю до окончания боевой операции ${ }^{8}$. Через два года, в августе 1944 года, отважный разведчик погиб на территории Польши.

Младший сержант Фаиз Сарсенбаев 1910/1913 г.р. удостоился нескольких боевых наград. Исполняющий обязанности командира взвода конной разведки был представлен в сентябре 1944 к Ордену „Красной Звезды“. Находясь на боевом задании, он был окружен группой противника. Сержант вступил с врагами в неравную схватку, уничтожил огнём из автомата четырёх немецких солдат и доставил в штаб точные данные о расположении частей противника ${ }^{9}$.

Разведчик взвода пешей разведки Канапья/Конон Раев 1923 г.р. удостоился вторично Медали „За отвагу“ после того, как в марте 1945 года с группой захвата ворвался в траншею противника, уничтожил трёх германских солдат и взял одного в плен. Пленный сообщил ценные сведения ${ }^{10}$.

За два с половиной года на фронте командир отделения разведки 23летний Иван И. Некрасенко (1922-1945) заслужил четыре боевых награды. Приказ о последнем награждении ефрейтора „Орденом Отечественной войны II“ степени вышел после его гибели, в конце мая 1945 года. 25 апреля разведчик обнаружил батарею противника. После чего подразделения Красной Армии смогли её уничтожить и занять населённый пункт в Германии. Через три дня противник перешёл в контратаку. Иван И. Некрасенко первым бросился в бой, увлекая за собой других бойцов. Уничтожив несколько вражеских солдат, ефрейтор погиб смертью храбрых ${ }^{11}$.

Разведчик отдельной разведроты в составе 63 Армии Брянского Фронта Гаяс С. Ибатулин 1916 г.р. был представлен к правительственным наградам дважды за две недели во время Орловской наступательной операции. Командир полка писал в июле 1943 в наградном листе (медаль „За отвагу“), что сержант Ибатулин „всё время идёт в боевых порядках при занятии населённого пункта, [...] ворвался первым в населённый пункт Масловка, где смело и бесстрашно действовал." Ордена „Красной Звезды“ младший сержант удостоился за то, что во время боевых действий разведроты „несмотря на обстрел врага, своевременно держал связь с группами разведчиков", передавая нужные сведения в штаб дивизии ${ }^{12}$. Через полгода Гаяс С. Ибатулин скончался в госпитале от ран.

Не только ремовские офицеры, сержанты и разведчики отличились на фронтах ВОВ, но и рядовые красноармейцы. Коммунист из Н. Киреевки Ергазы Карымсаков 1916 г.р. принимал участие в обороне Сталинграда. Через два года, в августе 1944 года, наводчик орудия миномётного полка был представлен своим командиром к „Ордену Славы III степени“, а награждён

\footnotetext{
8 Приказ подразделения Калининского фронта от 18.12.1942. ЦАМО. Ф. 33. Оп. 682526. Д. 866. Л. 2.

${ }^{9}$ Наградной лист от 15.09.1944. ЦАМО. Ф. 33. Оп. 690155. Д. 4778. Л. 15

${ }^{10}$ Приказ подразделения от 07.03.1945. ЦАМО. Ф. 33. Оп. 687572. Д. 2758. Л. 3.

${ }^{11}$ Наградной лист от 08.05.1945. ЦАМО. Ф. 33. Оп. 690306. Д. 3313. Л. 90.

12 Наградной лист от 24.07.1943. ЦАМО. Ф. 33. Оп. 682526. Д. 1865. Л. 57.
} 
„Орденом Отечественной войны II степени“. „Бесстрашный гвардеец" был ранен осколком разорвавшейся мины 19 июля, но от лечения в госпитале отказался. На следующий день он не воспользовался освобождением от участия в бою. Красноармеец навёл на открытом участке всего за 4 минуты орудие в цель - на скопление вражеской пехоты. ${ }^{13}$

Когда летом 1942 летное поле у города Белая Калитва бомбили две дюжины Юнкерсов Нуруш Ищанов первым бросился тушить загоревшийся на стоянке ЯК-1. Товарищи быстро пришли ему на помощь и истребитель уже скоро вновь бороздил небо. Красноармеец хорошо освоил обязанности фринишёра стартовой команды и по сведениям командира батальона предотвратил при посадке аварии более ста самолётов. Через год Нуруш получил необычное боевое задание - обслуживать ложный аэродром. Германские пилоты должны были поверить в то, что аэродром действующий. Заслышав в небе гул вражеских бомбардировщиков, красноармеец выбегал со своими сослуживцами с зажёнными фонарями на лётное поле. Сигнальными огнями солдаты изображали панику на „аэродроме“. Они выполняли своё боевое задание образцово, и вражеские пилоты попались таки на удочку. Чтобы стереть советскую „технику" с лица земли, они тратили в большом количестве боеприпасы, обстреливая поле пушечно-пулемётным огнём и сбрасывая вниз бомбы. Благодаря команде ложного аэродрома, техника и персонал большого, действующего неподалёку, советского военного аэродрома оставались невредимыми. Эта история - не описание сцен из художественного фрильма послевоенных лет „Беспокойное хозяйство“. Факты изложены в наградном листе (медаль "За боевые заслуги") фринишера аэродромного обслуживания 4 Воздушной Армии Северо-Кавказского фрронта, уроженца с. Ремки Нуруша Ищанова ${ }^{14}$. В отличии от большинства ушедших на фрронт односельчан, красноармеец остался в живых и смог праздновать Победу 9 мая 1945 года.

В казачьих войсковых частях 3-его отдельного гвардейского дивизиона связи (3 гв. кк Юго-Западного фронта) воевали два ремовца - Александр М. Пазий и Николай Ф. П/Коверьев. Гвардии казак и кандидат в члены ВКП(б) А. М. Пазий 1920 г.р. умело владел в наступательных боях своим ручном пулемётом. Его командиры дважды, в августе 1944 и в апреле 1945 года, представили его к „Ордену Славы III степени“. Командир полка майор Шахшаев живописно описал картину подвигов казака в наградном листе: „При наступлении на село Рудаевичи [...] гвардии казак Пазий [...] шёл в головном дозоре. Внезапно из засады наперерез дороги вышли два танка противника, на бортах которых находилась группа немецких автоматчиков. Казак Пазий быстро залёг и дал очередь из своего пулемёта. Пять немцев сразу же свалились с борта головного танка, после чего танки повернулись обратно и ушли. Отважно продвигаясь дальше, Пазий [...] обстрелял их [солдат противника] из пулемёта. Оставив на месте трёх убитых, группа немцев в беспорядке разбежалась". Незадолго до Дня Победы, в бою за селение Бачала гв. казак уничтожил из своего ручного пулемёта весь расчёт зенитной пушки (11 солдат) и захватил саму пушку в исправном состоянии ${ }^{15}$. В донесениях о потерях указана аббревиатурой „ВМН" причина выбытия из действующей армии в 1942-1943 гг. трёх ремовцев-фрронтовиков. Указанным сокращением

\footnotetext{
${ }_{13}^{13}$ Наградной лист от 24.07.1944. ЦАМО. Ф. 33. Оп. 690155. Д. 4858. Л. 53.

${ }_{15}^{14}$ Наградной лист от 14.06.1943. ЦАМО. Ф. 33. Оп. 682526. Д. 1340. Л. 125.

${ }^{15}$ Наградной лист от 27.08.1944. ЦАМО. Ф. 33. Оп. 686196. Д. 76. Л. 68.Наградной лист от 17.04.1945. ЦАМО. Ф. 33. Оп. 690306. Д. 1197. Л. 51.
} 
пометили наказание через расстрел военнослужащих по приговору военного трибунала или особого совещания. Советские войска отступали с первых дней войны по основным фронтам целый год, до лета 1942 года. Боевой дух солдат пал и даже многие командиры прониклись пессимизмом. Чтобы остановить массовое отступление советских войск Нарком Обороны издал во время Сталинградской битвы приказ № 227 от 28.07.1942, известный в народе как „Ни шагу назад“. В числе различных наказаний упомяналось и новое - штрафные батальоны. Сотрудники заградительных отрядов возвратили в годы войны большую часть задержанных в свои части. Остальных арестовывали, расстреливалиинаправляли в штрафрные роты.

Ещё до выхода приказа армейское командование применяло против отступивших самовольно военнослужащих, паникёров, дезертиров и тд. различные наказания, вплоть до расстрела. В июне 1942 года после боя не нашли 25-летнего Аюпа Турганбаева 1917 г.р. и шесть его сослуживцев 1251 сп Волховского Фронта. Так как все без вести пропавшие, заранее подозревались в возможной измене Родине, военный трибунал приговорил ремовца и его боевых товарищей к высшей мере наказания заочно ${ }^{16}$. Через месяц в 62 Армии Сталинградского Фронта был приговорен к расстрелу 19летний красноармеец Павел П. Пазий 1923 г.р. ${ }^{17}$ Приговор „10 лет лишения свободы“ получил красноармеец 261 сп Сакен Оразбаев (по другой версии Коратай Джоянов) 1916 г.р. в январе 1942 в Томском гарнизоне ${ }^{18}$. В военной статистике тех лет часто встречаются ошибки. Осуждённые заочно и пропавшие без вести могли остаться в живых - попасть за линию фронта, в окружение и плен. Иногда приговор не приводился в исполнение. Расстрел заменяли переводом в штрафрную роту.

Документы военного времени повествуют о трагической судьбе ремовского офицера Григория Никифоровича Галушко (1922/1923-1943). Боевая биография старшего лейтенанта начиналась геройски. В 20 лет он уже командовал ротой и удостоился, единственный из всех фронтовиков-ремовцев, „полководческого“ Ордена. Его боевая награда - „Орден Александра Невского“ предназначалась для младшего командного состава Красной Армии. Ею награждали в первую очередь „за личную отвагу, мужество и храбрость, и умелое командование, обеспечивающее успешные действия своих частей" (Статут "Ордена Александра Невского (СССР). (http://mondvor.narod.ru/ONevsk.html). Командир 151 сп 8 сд. капитан Касперович представил в начале фревраля 1943 года старшего лейтенанта Г.Н. Галушко к одному из высших орденов СССР - Ордену „Красного Знамени“. В наступательном бою командир стрелковой роты „штурмовал опорный пункт противника. Он первый бросился в окопы, увлекая за собой роту, в результате чего подавил шесть огневых точек и уничтожил около 50 немецких солдат и офицеров"19. Через несколько недель командование Брянского фрронта обьявило в своём приказе о присуждении офицеру Галушко вместо Ордена „Красного Знамени“ „Ордена Александра Невского“.

Через полгода после награждения, в июле 1943 года, ротный учавствовал в составе 287 сд 63 Армии Брянского Фронта в Орловской наступательной операции, также как и его земляк сержант-разведчик Гаяс С. Ибатулин. В то

\footnotetext{
${ }_{17}^{16}$ Донесение о потерях Волховского фронта от 28.07.1942. ЦАМО. Ф. 58. Оп. 818883. Д. 786. Л. 42

17 Донесение о безвозвратных потерях Сталинградского фронта от 22.08.1942. ЦАМО. Ф. 58. Оп. 818883. Д 779. Л. 3.

${ }_{18}$ Донесение о безвозвратных потерях гарнизона г. Томска от 25.05.1942. ЦАМО. Ф. 58. Оп. 818883. Д. 1523. Л. 8.

${ }^{19}$ Наградной лист от 02.02.1943. ЦАМО. Ф. 33. Оп. 682525. Д. 133. Л. 40.
} 
время как разведчик удостоился наград, лейтенант Галушко был расстрелян в период с 10 по 20 июля на высоте 255,2 у села Архангельское Орловской области с фрормулировкой „за отступление с боевого рубежа"20. Очевидноофицер попал под действие приказа „Ни шагу назад". Самовольное отступление военного начальника от приказа и самовольное оставление поля сражения во время боя считалось воинским преступлением и за это предусматривалась смертная казнь.

На основании скудной информации из донесения о потерях 287 сд за июнь-июль 1943 невозможно выявить обстоятельства случившегося. Вполне вероятно, что в фондах ЦАМО РФ хранится личное дело офицера, которое могло бы прояснить ситуацию и дать ответы на вопросы: Какое задание выполняла рота лейтенанта Галушко в тот злополучный для офицера день? Отступил он один или со своими бойцами? Остались ли в живых его подчинённые?

Есть некоторые основания не подозревать ст. лейтенанта в малодушии. По оценке своего командира в наградном листе офицер доказывал в боях „исключительное мужество“. Приказ Сталина „Ни шагу назад" был издан за год до события, и ротному было известно, что ему, как командиру грозит за отступление расстрел. Однако отступив с остатком своего подразделения, он мог спасти жизни своих подчинённых.

Исследователи Курской битвы, например, А. Исаев и П. Букейханов упомянают в своих публикациях боевую обстановку с 14 по 18 июля 1943 года у железнодорожной станции Архангельское. (Букейхайнов, 2013; Исаев, 2015). Орловская наступательная операция „Кутузов" была решающей битвой лета 1943 года и имела своей целью разгром Орловского стратегического плацдарма группы армий „Центр“ противника и освобождение города. Операция проводилась с 12 июля по 18 августа 1943 года в рамках Курской битвы. Сложность задачи 287 сд 63 А Брянского Фронта состояла в том, что на оборонительном рубеже Вермахта - река ОлешняПодмаслово-Архангельское находились основные узлы сопротивления противника. Для обороны военного аэродрома германское командование не жалело техники и личного состава. Здесь в середине июля шли ожесточённые бои. В них с обоих сторон учавствовали танки, самолёты и артиллерия. За два года оккупации у противника было достаточно времени для создания развитой системы обороны. Наступление усложнял ландшафрт местности - наличие рек, а также выгодно расположенных и хорошо укреплённых противником высот. Генерал армии С. М. Штеменко пишет в своих воспоминаниях, что к середине июля на Брянском фрронте возникло кризисное положение: „Оборона противника была здесь очень сильной, с большим количеством долговременных огневых точек. Пехота никак не могла одолеть ее без непосредственной поддержки бронесредств". (Штеменко,1989). Войска только через пять дней смогли прорвать оборону. Вероятнее всего людские потери не имели для советского командования в деле достижения поставленной задачи решающего значения. Приказ командования „наступать" был выполнен большой кровью. Безвозвратные и санитарные потери Брянского фрронта в операции „Кутузов" достигали 40 \% личного состава. (Кривошеев и др., 2001).

Война требовала неимоверных сил от ремовцев не только на боевых фронтах, но и в тылу. Юноши допризывного возраста и непригодные к

\footnotetext{
${ }^{20}$ Донесение о безвозвратных потерях 31224 от 24.08.1943. ЦАМО. Ф. 58. Оп. 18001. Д. 750. Л. 20.
} 
строевой службе односельчане были мобилизованы в трудовые лагеря НКВД на тяжёлые работы. Будущий бухгалтер колхоза „XX партсъезд" Рашид М. Мухаев работал до 1948 года на шахте г. Караганда, а Владимир П. Нестерюк 1928 г.р. в г. Гурьеве. Инвалид Первой Мировой Войны Емельян Герцовский из Переменовского с/с вспоминал, что смог выжить в своей трудовой колонне, в окружении озлобленных заключённых и при тяжёлых материально-бытовых условиях, благодаря поддержке земляка-"великана" из Н. Киреевки.

В годы войны часть бывших военнопленных и непригодные к строевой службе раненые, а после войны и другие фронтовики распределялись на стройки и предприятия для скорейшего восстановления инфраструктуры страны. Из наградного листа (медаль "За боевые заслуги") Кали Турганбаева следует, что он был занят в июле 1945 года в военизированной охране (BОXР) завода 434 Наркомнефти в туркменском городе Красноводск. Из действующей армии мл. сержант выбыл в январе этого года из-за тяжёлого ранения ${ }^{21}$.

В то время как трудовые лагеря мужчин находились не только в Казахстане, но и в других республиках СССР, девушки командировались на различные работы на территории области. 16-летняя жительница с. Ремки Екатерина Н. Галушко/Нестерюк 1928 гр. была задействована на уборке урожая в районном селе Маканчи на юге области. Девушек доставили туда за 600 км на повозках. Сёстры Герцовские из Переменовского с/с были командированы для работы в г. Семипалатинск. Елена Е. 1928 г.р. шила униформы с другими девушками из округи на эвакуированной в город швейной фрабрике „Большевичка Украины". Её сестра Мария Е. проработала кочегаром речного судна на реке Иртыш всю войну. Берта И. Бангерт 1921 г.р. из Орловского с/с выполняла строительно-дорожные работы на станции Аул.

Война искалечила жизни не только взрослым, но и украла у детей счастливое детство. К нравственным страданиям - отсутствие или потеря отцов и старших братьев добавились фризические - голод и непосильная работа в колхозе. Касымхан Турганбаев вспоминал, как ребенком помогал в сельском хозяйстве. Его сажали на телегу, запряженную быками. Чтобы он не упалуснув, его привязывали.

После войны правительство оценило вклад ремовцев в Победу, удостоив трудармейцев, работников тыла и ветеранов ВОВ медалей: „За доблестный труд в Великой Отечественной войне 1941-1945 гг.", „За трудовое отличие“, „За трудовую доблесть“ и „Ветеран труда“. Независимо от того щедро или нет армейское командование и органы власти наградили тех или иных односельчан за боевую службу или труд, все они заслуживают благодарности и памяти земляков.

Заключение. История Великой Отечественной войны является предметом исследовательских интересов ученых постсоветского и зарубежного пространства. В последнее время предложенная научная проблематика затрагивает вопросы участия регионов, как например вклад восточноказахстанцев в победу Великой Отечественной войне. Вместе с тем, «Новая историческая наука» диктует новые методологические тренды, как микроисторический, антропологический подходы, что детерминировало наш интерес к вкладу жителей восточной части Бородулихинского района в Победу.

\footnotetext{
${ }^{21}$ Наградной лист от 14.07.1945. ЦАМО. Ф. 33. Оп. 744807, Д. 910. Л. 327.
} 
Множество страниц Великой Отечественной войны еще не прочитаны, в том числе неизвестны имена больше полусотни павших ремовцев. Публикация архивных документов на сайтах Министерств Обороны России и Казахстана расширила источниковую базу краеведов и способствует изучению региональной истории. Новые документы ЦАМО введены в статье в научный оборот, составлен и модифрицирован при помощи устного опроса и анкетирования мемориальный список и даны биографические справки. На локальном примере реконструирован образ фронтового поколения.

Статья способствуют расширению краеведческих знаний и затрагивает тему сохранения исторической памяти о войне в регионе. Введение в научный оборот биографий ремовцев преследует в первую очередь мемориальную цель. Собранные фракты являются попыткой противостоять забвению, формируют коллективную память земляков, а вместе с тем и их гражданскую идентичность.

Исследование может представлять интерес как для краеведов и учителей истории, так и для уроженцев ВКО, интересующихся своей родословной. Выявленные факты способствуют дальнейшему изучению истории переселенческих посёлков Томской губернии, основанных в начале XX века

\section{Әдебиеттер тізімі / Список литературы}

1. Аманжолов, 2012 - Аманжолов М. М. Река моей жизни: Воспоминания-эссе. Алматы: Фолиант, 2012. 279 c.

2. Букейханов, 2013 - Букейханов П. Курская битва. Наступление. Операция «Кутузов». Операция «Полководец Румянцев». Июль-август 1943. Москва: «ЗАОИздательство Центрполиграф», 2013. 671 с.

3. Воробьев, 2014 - Воробьев С. М. Реабилитация как способ возмещения морального вреда советским военнопленным в СССР // История государства и права. 2014. № 2. С. 59-63. [Электронный ресурс] / URL: http://отрасли-права.pфp/article/6425 (Дата обращения 20.03.2019).

4. Даутов, 2011 - Даутов М. Переменовка моя: Стихи и воспоминания. Семей: Талант, 2011. 205 с.

5. Исаев, 2015 - Исаев А. В. Освобождение: Переломные сражения 1943 года. Москва: ООО «Яуза-пресс», 2015. 544 с.

6. Карта, 1911 - Карта Томской губернии 1911 года переселенческой районной организации. [Электронный ресурc] / URL: http://www.etomesto.ru/map-tomsk_guberniya-1911. (Дата обращения 10.04.2019).

7. Книга Памяти, 1996 - Министерство печати и массовой информации Республики Казахстан. Книга Памяти. Боздақтар: Семипалатинская область. Том 2. Алматы: «Казах Энциклопедия» 1996.

8. Кривошеев, 2001 - Кривошеев Г.Ф. и др. (Под общ. ред. ). Россия и СССР в войнах XX века: Потери вооружённых сил. Статистическое исследование. Москва: Олма-Пресс, 2001. С. 453. [Электронный ресурс] / URL: http://lib.ru/MEMUARY/1939-1945/KRIWOSHEEW/poteri.txt\#w06.htm-

Тос536603381 (Дата обращения 15.04.2019).

9. Масюк, 2005 -Масюк М. Д. Героическая девушка. // К новым Рубежам. Общественнополитическая газета Локтевского района Алтайского края. Май 2005.

10. НРК, 2009 - Агентство Республики Казахстан по статистике. Население Республики Казахстан. Итоги Национальной переписи населения Республики Казахстан 2009 года. Том 1 11. Статистический сборник. Под ред. Смаилова А. А. Астана: 2011.242 с. [Электронный ресурc] / URL: stat.gov.kz (Дата обращения 15.04.2019).

12. Недзелюк, 2006 - Недзелюк Т.Г. Римско-католическая община Мариенбурга: Особенности локального менталитета // AusSibirien 2006. С. 87-90. [Электронный ресурс] / URL:http://library.ikz.ru/georg-steller/aus-sibirien-2013-2006/nedzelyuk-t.g.-rimsko-katolicheskayaobschina (Дата обращения: 10.06.2017).

13. Справочник, 2006 - Центр документации новейшей истории ВКО. Управление архивами ВКО. Справочник по истории административно-территориального деления Семипалатинской области 1939-1997 гг. Семипалатинск: 2006. 238 с. [Электронный ресурc] / URL: http://referatdb.ru/ pravo/67004/index.html (Дата обращения: 20.04.2019). 
14. Shaidurov, 2018 - Shaidurov V. N. The German catholic community of Marienburg from the end of the $19^{\text {th }}$ till the beginning of the $20^{\text {th }}$ century: Some aspects of the local history. Rusin 2018. Volume 52. Issue 2. S. 288-308. [In English]. [Электронный ресурc] / URL: http://journals. tsu.ru/rusin/\&journal_page=archive\&id=1733\&article_id=38579 (Датаобращения: 20.04.2019).

15. Штеменко, 1989 - Штеменко С.М. Генеральный штаб в годы войны. Москва: Воениздат, 1989. [Электронный ресурс] / URL: http://militera.lib.ru/memo/russian/shtemenko/09.html. (Дата обращения: 10.05.2019).

\section{References}

Amanzholov, 2012 - Amanzholov M. M. Reka moej zhizni: Vospominaniya-esse. Almaty: Foliant, 2012. 279 s. (in Rus.)

Bukejhanov, 2013 - Bukejhanov P. Kurskaya bitva. Nastuplenie. Operaciya «Kutuzov». Operaciya «Polkovodec Rumyancev». Iyul'-avgust 1943. Moskva: «ZAO Izdatel'stvo Centrpoligraf», 2013. 671 c.(in Rus.)

Vorob'ev, 2014 - Vorob'ev S. M. Reabilitaciya kak sposob vozmeshcheniya moral'nogo vreda sovetskim voennoplennym v SSSR // Istoriya gosudarstva i prava. 2014. № 2. S. 59-63. [Elektronnyj resurs] / URL: http://otrasli-prava.rf/article/6425 (Data obrashcheniya 20.03.2019).(in Rus.)

Dautov, 2011 - Dautov M. Peremenovka moya: Stihi i vospominaniya. Semej: Talant, 2011. 205 c.(in Rus.)

Isaev, 2015 - Isaev A. V. Osvobozhdenie: Perelomnye srazheniya 1943 goda. Moskva: OOO «YAuzapress», 2015. $544 \mathrm{c}$

Karta, 1911 - Karta Tomskoj gubernii 1911 goda pereselencheskoj rajonnoj organizacii. [Elektronnyj resurs] / URL: http://www.etomesto.ru/map-tomsk_guberniya-1911. (Data obrashcheniya 10.04.2019).(in Rus.)

Kniga Pamyati, 1996 - Ministerstvo pechati i massovoj informacii Respubliki Kazahstan. Kniga Pamyati. Bozdaktar: Semipalatinskaya oblast'. Tom 2. Almaty: «Kazah Enciklopediya» 1996. (in Rus.)

Krivosheev, 2001 - Krivosheev G. F. i dr. (Pod obshch. red. ). Rossiya i SSSR v vojnah XX veka: Poteri vooruzhyonnyh sil. Statisticheskoe issledovanie. Moskva: Olma-Press, 2001. C. 453. [Elektronnyj resurs] / URL: http://lib.ru/MEMUARY/1939 1945/KRIWOSHEEW/poteri.txt\#w06.htmToc536603381 (Data obrashcheniya 15.04.2019).(in Rus.)

Masyuk, 2005 - Masyuk M. D. Geroicheskaya devushka. // K novym Rubezham. Obshchestvennopoliticheskaya gazeta Loktevskogo rajona Altajskogo kraya. Maj 2005.(in Rus.)

HPK, 2009 - Agentstvo Respubliki Kazahstan po statistike. Naselenie Respubliki Kazahstan. Itogi Nacional'noj perepisi naseleniya Respubliki Kazahstan 2009 goda. Tom 1(in Rus.)

Statisticheskij sbornik. Pod red. Smailova A. A. Astana: 2011. 242 s. [Elektronnyj resurs] / URL: stat.gov.kz (Data obrashcheniya 15.04.2019).(in Rus.)

Nedzelyuk, 2006 - Nedzelyuk T. G. Rimsko-katolicheskaya obshchina Marienburga: Osobennosti lokal'nogo mentaliteta // Aus Sibirien 2006. C. 87-90. [Elektronnyj resurs] / URL: http://library.ikz.ru/georg-steller/aus-sibirien-2013-2006/nedzelyuk-t.g.-rimsko-katolicheskayaobschina (Data obrashcheniya: 10.06.2017).(in Rus.)

Spravochnik, 2006 - Centr dokumentacii novejshej istorii VKO. Upravlenie arhivami VKO. Spravochnik po istorii administrativno-territorial'nogo deleniya Semipalatinskoj oblasti 1939 1997 gg. Semipalatinsk: 2006. 238 s. [Elektronnyj resurs] / URL: http://referatdb.ru/pravo/67004/index.html (Data obrashcheniya: 20.04.2019).(in Rus.)

Shaidurov, 2018 - Shaidurov V. N. The German catholic community of Marienburg from the end of the 19th till the beginning of the 20th century: Some aspects of the local history. Rusin 2018. Volume 52. Issue 2. S. 288 308. [In English]. [Elektronnyj resurs] / URL: http://journals.tsu.ru/rusin/ \&journal_page=archive\&id=1733\&article_id=38579 (Data obrashcheniya: 20.04.2019).(in Rus.)

SHtemenko, 1989 - SHtemenko S. M. General'nyj shtab v gody vojny. Moskva: Voenizdat, 1989. [Elektronnyj resurs] / URL: http://militera.lib.ru/memo/russian/shtemenko/09.html. (Data obrashcheniya: 10.05.2019).(in Rus.) 